\title{
Characterisation of CCT271850, a selective, oral and potent MPS1 inhibitor, used to directly measure in vivo MPS1 inhibition vs therapeutic efficacy
}

\author{
Amir Faisal ${ }^{1,3}$, Grace W Y Mak ${ }^{1}$, Mark D Gurden ${ }^{2}$, Cristina P R Xavier ${ }^{1,4}$, Simon J Anderhub ${ }^{1,5}$, \\ Paolo Innocenti ${ }^{1}$, Isaac M Westwood ${ }^{1}$, Sébastien Naud ${ }^{1}$, Angela Hayes ${ }^{1}$, Gary Box ${ }^{1}$, Melanie R Valenti ${ }^{1}$, Alexis \\ K De Haven Brandon ${ }^{1}$, Lisa O'Fee ${ }^{1}$, Jessica Schmitt ${ }^{1}$, Hannah L Woodward ${ }^{1}$, Rosemary Burke ${ }^{1}$, \\ Rob L M vanMontfort ${ }^{1}$, Julian Blagg ${ }^{1}$, Florence I Raynaud ${ }^{1}$, Suzanne A Eccles ${ }^{1}$, \\ Swen Hoelder ${ }^{1}$ and Spiros Linardopoulos ${ }^{\star 1,2}$ \\ ${ }^{1}$ Cancer Research UK Cancer Therapeutics Unit, Division of Cancer Therapeutics, The Institute of Cancer Research, London, UK \\ and ${ }^{2}$ Breast Cancer Now, Division of Breast Cancer Research, The Institute of Cancer Research, London, UK
}

Background: The main role of the cell cycle is to enable error-free DNA replication, chromosome segregation and cytokinesis. One of the best characterised checkpoint pathways is the spindle assembly checkpoint, which prevents anaphase onset until the appropriate attachment and tension across kinetochores is achieved. MPS1 kinase activity is essential for the activation of the spindle assembly checkpoint and has been shown to be deregulated in human tumours with chromosomal instability and aneuploidy. Therefore, MPS1 inhibition represents an attractive strategy to target cancers.

Methods: To evaluate CCT271850 cellular potency, two specific antibodies that recognise the activation sites of MPS1 were used and its antiproliferative activity was determined in 91 human cancer cell lines. DLD1 cells with induced GFP-MPS1 and HCT116 cells were used in in vivo studies to directly measure MPS1 inhibition and efficacy of CCT271850 treatment.

Results: CCT271850 selectively and potently inhibits MPS1 kinase activity in biochemical and cellular assays and in in vivo models. Mechanistically, tumour cells treated with CCT271850 acquire aberrant numbers of chromosomes and the majority of cells divide their chromosomes without proper alignment because of abrogation of the mitotic checkpoint, leading to cell death. We demonstrated a moderate level of efficacy of CCT271850 as a single agent in a human colorectal carcinoma xenograft model.

Conclusions: CCT271850 is a potent, selective and orally bioavailable MPS1 kinase inhibitor. On the basis of in vivo pharmacodynamic vs efficacy relationships, we predict that more than $80 \%$ inhibition of MPS1 activity for at least $24 \mathrm{~h}$ is required to achieve tumour stasis or regression by CCT271850.

Dividing cells faithfully transmit their genetic information into daughter cells by accurately segregating duplicated chromosomes during mitosis. This is ensured by a surveillance mechanism called the spindle assembly checkpoint (SAC, also known as mitotic checkpoint), which delays mitotic progression until all chromosomes are properly attached to spindle microtubules (Musacchio and Salmon, 2007; Lara-Gonzalez et al, 2012; Foley and Kapoor, 2013). Inactivation of SAC results in premature anaphase onset and, therefore, missegregation of erroneously attached chromosomes. This consequently leads to chromosomal 
instability and aneuploidy that can either cause cell death or tumorigenesis depending on the strength of checkpoint abrogation (Dobles et al, 2000; Kops et al, 2004, 2005; Gordon et al, 2012). The dual specificity kinase, MPS1 (also known as TTK), is one of the core proteins that regulates SAC activation by initiating and transducing an inhibitory signal from unattached kinetochores to anaphase-promoting complex/cyclosome (APC/C), an E3 ubiquitin ligase (Musacchio and Salmon, 2007). Consequently, APC/Cmediated degradation of the mitotic proteins cyclin B and securin, normally required for mitotic exit, is inhibited and cells remain arrested in mitosis until all chromosomes are properly attached (Lara-Gonzalez et al, 2012). Incidentally, MPS1 kinase activity can also regulate chromosomal attachment and error correction (Maure et al, 2007; Jelluma et al, 2008). Loss of MPS1 activity, therefore, results in both abrogation of SAC function and chromosomal misalignment, ultimately leading to severe aneuploidy and apoptotic cell death (Schmidt et al, 2005; Jelluma et al, 2008; Hewitt et al, 2010; Kwiatkowski et al, 2010; Santaguida et al, 2010).

A large majority of human cancers are characterised by aneuploidy and chromosomal instability, despite normal cells being highly intolerant to both phenotypes (Orr et al, 2015). Overexpression of several SAC components, including MPS1 kinase, have been suggested as one of the mechanisms through which tumour cells can tolerate high aneuploidy and chromosomal instability (Yuan et al, 2006; Daniel et al, 2011). MPS1 is overexpressed in various human tumours, including breast, pancreatic, thyroid and glioblastoma, and its higher expression levels correlate with poor prognosis in many of these tumours (Salvatore et al, 2007; Daniel et al, 2011; Tannous et al, 2013; Slee et al, 2014). Reduction in MPS1 levels or activity in such tumours can result in loss of cell viability (Daniel et al, 2011; Slee et al, 2014), or in increased sensitivity to low doses of microtubulepolymerising agents such as docetaxel (Tannous et al, 2013; Maia et al, 2015). Therefore, MPS1 inhibition represents an attractive strategy to target cancers, especially those with chromosomal instability (Manchado et al, 2012). Several structurally diverse MPS1 inhibitors have been discovered and have undergone preclinical assessments in recent times (Liu and Winey, 2012). These include AZ3146 (Hewitt et al, 2010), NMS-P715 (Colombo et al, 2010), MPI-0479605 (Tardif et al, 2011), CCT251455 (Naud et al, 2013), MPS1-IN-3 (Tannous et al, 2013) and compounds from Shionogi (Kusakabe et al, 2015) and Bayer (Jemaa et al, 2013).

The availability of robust pharmacodynamic (PD) biomarkers is critical for any modern drug development programme (Workman, 2003). Inhibition of histone $\mathrm{H} 3$ phosphorylation at $S 10$, or downregulation of mitotic proteins such as cyclin B, have been widely used as biomarkers for SAC over-ride and the accompanying mitotic exit that results from cellular inhibition of MPS1 (Colombo et al, 2010; Kwiatkowski et al, 2010; Tardif et al, 2011; Naud et al, 2013). Of several MPS1 inhibitors that have been reported, only a few have demonstrated direct MPS1 inhibition in cells using either phospho-specific antibodies for the MPS1 T676 autophosphorylation site, or a change in mobility of MPS1 by SDS-PAGE (Colombo et al, 2010; Hewitt et al, 2010; Kwiatkowski et al, 2010; Tardif et al, 2011). For many inhibitors that have been evaluated in in vivo models, although not exclusively, histone H3 phosphorylation at S10 has been the biomarker of choice to demonstrate MPS1 inhibition in tumours (Colombo et al, 2010; Jemaa et al, 2013). SAC over-ride and consequential reduction in histone $\mathrm{H} 3$ phosphorylation at $\mathrm{S} 10$ are, however, not specific for MPS1 inhibition and can be regulated by other kinases involved in the SAC (Mao et al, 2003; Santaguida et al, 2011; Saurin et al, 2011).

Our efforts to discover MPS1 inhibitors with favourable biochemical, cellular, pharmacokinetic and $\mathrm{PD}$ and in vivo properties for a clinical candidate have yielded inhibitors from two different chemical series: CCT251455 (Naud et al, 2013) and CCT271850 (Innocenti et al, 2016). Here we report an extensive cellular characterisation and in vivo parmacodynamic $v s$ efficacy relationship of CCT271850.

\section{MATERIALS AND METHODS}

Cell culture, transfection and proliferation assay. Cell lines were obtained from the American Type Culture Collection and grown in their recommended culture medium, supplemented with 10\% FBS at $37{ }^{\circ} \mathrm{C}$ in $5 \% \mathrm{CO}_{2}$. In-house authentication of cell lines by SNP profiling was carried out and cultured cells were passaged for less than 6 months before replacement from early-passage frozen stocks. Cells were regularly screened for Mycoplasma, using a PCR-based assay (VenorGem; Minerva Biolabs, Berlin, Germany). Transfections were carried out at $\sim 80 \%$ confluency with the plasmids indicated, using Lipofectamine LTX (15338030, Life Technologies, Carlsbad, CA, USA) according to the manufacturer's instructions. Cell proliferation assays were carried out by colorimetric MTT method (Sigma, St Louis, MO, USA) as described elsewhere (Mosmann, 1983). Briefly, cells were plated in 96-well plates at 2000-5000 cells per well (depending on the cell line) followed by treatment with two-fold dilutions of $0-25 \mu \mathrm{M}$ drug for $72 \mathrm{~h}$. Absorbance was measured at $570 \mathrm{~nm}$ with the Wallac VICTOR2 1420 Multilabel Counter (PerkinElmer, Waltham, MA, USA).

Immunoprecipitation and immunoblotting. For immunoprecipitation assay, $1 \mathrm{mg}$ of total cell/tumour lysate was incubated with $8 \mu \mathrm{g}$ of $\mathrm{pTpS}^{33 / 37}$ antibody (44-1325 G, Life Technologies) for $1 \mathrm{~h}$ with rotation at $4{ }^{\circ} \mathrm{C}$. The antibody/protein complexes were captured by further incubation with Protein A sepharose beads for $1 \mathrm{~h}$ with rotation at $4{ }^{\circ} \mathrm{C}$. Beads were washed three times with completed lysis buffer, followed by boiling for $10 \mathrm{~min}$ in $2 \times$ LDS sample buffer. The samples were used for immunoblotting with total MPS1 antibodies as described below.

For immunoblotting, cells were lysed either in NP-40 alternative (Calbiochem, Merck Millipore, Billerica, MA, USA) lysis buffer $(120 \mathrm{mmol} / \mathrm{l} \mathrm{NaCl}, 50 \mathrm{mmol} / \mathrm{l}$ Tris-HCl, pH 7.5, 1\% NP-40 supplemented with phosphatase and protease inhibitors) or $2 \times$ LDS sample buffer (Invitrogen, Carlsbad, CA, USA). Equal amounts of proteins were resolved by $4-12 \%$ Bis-Tris NuPAGE gels (Invitrogen), transferred to nitrocellulose (Whatman, Buckinghamshire, UK) membranes and immunoblotted with specific antibodies. For gel shift analysis, samples were prepared in SDSsample buffer and resolved by $10 \%$ SDS-PAGE.

Immunofluorescence and time-lapse microscopy. For immunofluorescence, cells were pretreated with CCT271850 for $1 \mathrm{~h}$, then treated with nocodazole, MG132 and CCT271850 for additional $1 \mathrm{~h}$. Cells were fixed and stained according to the protocol previously described (Gurden et al, 2015). Primary antibodies used were as follows: anticentromere antibodies (ACA; ImmunoVision, Springdale, AR, USA, HCT-0100), BubR1 (BD Biosciences, San Jose, CA, USA, 612503), Mad1 (Abcam, Cambridge, UK, ab45286), Mad2 (Bethyl Laboratories Inc., Montgomery, TX, USA, A300301A), MPS1 (Invitrogen, 35-9100), MPS1 pT33pS37 (Life Technologies, 44-1325 G) and Zwint-1 (Abcam, ab84367). Images were acquired using a Zeiss LSM 710 confocal microscope and processed using the Volocity 3D Image analysis software (PerkinElmer). Time-lapse microscopy was performed in 96-well Ibidi plate (Thistle Scientific, Glasgow, UK) using a Diaphot inverted microscope (Nikon, Tokyo, Japan), in a humidified $\mathrm{CO}_{2}$ chamber at $37^{\circ} \mathrm{C}$, using a motorised stage (Prior Scientific, Cambridge, UK), controlled by Simple PCI software (Compix, Irvine, CA, USA). 
Flow cytometry. After treatment with CCT271850 for $24 \mathrm{~h}$, cells were fixed and stained as described previously (Gurden et al, 2015). Briefly, cells were fixed in $70 \%$ ethanol, washed in PBS, incubated in $10 \mu \mathrm{g} / \mathrm{ml}$ propidium iodide and $0.5 \%$ RNase (Sigma) for $30 \mathrm{~min}$ and analysed using LSRII flow cytometer (BD Biosciences). To stain for mitosis, cells were incubated for $1 \mathrm{~h}$ at $4{ }^{\circ} \mathrm{C}$ with antiMPM2 antibodies (Millipore, Billerica, MA, USA, 05-368), followed by 1 -h incubation at $4{ }^{\circ} \mathrm{C}$ with FITC-conjugated secondary antibodies (Life Technologies).

MSD assay. MSD assay for detection of autophosphorylation of MPS1 at pT33pS37 sites in cell lysates has previously been described (Naud et al, 2013). For MSD from tumours, samples were prepared in complete lysis buffer $(50 \mathrm{~mm} \mathrm{NaCl}, 20 \mathrm{~mm}$ Tris $\mathrm{pH}$ 7.5, 1 mм EDTA, 1 mм EGTA, 1\% ( $v / v)$ Triton X-100, $10 \mathrm{~mm}$ $\mathrm{NaF}$, protease inhibitor tablet and phosphatase inhibitor cocktails) and $25-37.5 \mu \mathrm{g}$ protein per well was used for the detection of phosphorylation at T33/S37. We also measured total MPS1 levels in these tumour samples with an MSD assay for GFP, which was developed using mouse monoclonal MPS1 antibody (Invitrogen, Cat no. 35-9100) as capture antibody and rabbit polyclonal GFP antibody (Abcam, Cat no. ab290 at 1:2000 dilution) as the detection antibody. Results were presented as the ratio of PhosphoMPS1/Total MPS1.

In vivo mouse $\mathrm{PK} / \mathrm{PD}$ study. Overall, $5 \times 10^{6}$ of MPS1doxycycline (Dox)-inducible DLD-1 human colorectal carcinoma cells were injected s.c. bilaterally into the flanks. Once tumours reached a mean diameter of $8-10 \mathrm{~mm}$, animals were put on Dox diet for 3 days and given an oral gavage bolus of Dox $(6 \mathrm{mg} /$ mouse) $24 \mathrm{~h}$ before dosing of compounds. Animals $(n=3$ per group) were dosed once daily with CCT271850 (50 or $100 \mathrm{mg} / \mathrm{kg}$ po) or vehicle ( $10 \%$ DMSO, $5 \%$ Tween $20,85 \%$ saline). Mice were culled at 2, 6, 12 and $24 \mathrm{~h}$ after dosing. Heparinised plasma was collected and tumours were snap-frozen for pharmacokinetics (PK) and PD biomarker analysis. For PK examination, compounds were extracted from whole blood, plasma and tissue homogenates with methanol-containing internal standards using established protocols. CCT271850 concentrations were determined using liquid chromatography/tandem mass spectrometry and PK were calculated using the Pharsight Phoenix Software (Mountain View, CA, USA, version 6.3). For PD examination, samples were lysed and analysed by MSD for pT33pS37and GFP levels and ratio of P-MPS1 (pT33pS37)/Total-MPS1 (GFP) in tumour samples at various time points after 50 and $100 \mathrm{mg} / \mathrm{kg}$ dosing were calculated.

Efficacy study. Three million HCT116 human colorectal carcinoma cells were injected s.c. into the right flanks of athymic mice. Therapy was initiated when tumours reached a mean diameter of $5 \mathrm{~mm}$ (indicated as day 0$)$. Control mice $(n=7)$ received vehicle (10\% DMSO, $5 \%$ Tween $20,85 \%$ saline) and treated mice $(n=8)$ were given CCT271850 at 50 and $100 \mathrm{mg} / \mathrm{kg}$ orally twice daily with a break after 1 week's dosing. Tumour volumes and body weights were measured three times weekly and the study was terminated on day 15 when all tumours were excised and weighed. Plasma and tumour samples were collected for pharmacokinetic and PD biomarker analysis at 2 and $6 \mathrm{~h}$ after the final dose.

All animal studies were approved by the local research ethics committee and carried out in accordance with the UK Animals (Scientific Procedures) Act 1986 and national guidelines (Workman et al, 2010).

\section{RESULTS}

CCT271850 potently inhibits MPS1 phosphorylation and activity in cells. CCT271850 (Figure 1A) is a novel and potent small molecule inhibitor of MPS1 kinase discovered through our lead optimisation studies on a pyridopyrimidine series of compounds (Innocenti et al, 2016; compound $34 \mathrm{~h}$ ). In an in vitro kinase assay, CCT271850 inhibited MPS1 activity with $\mathrm{IC}_{50}$ values of $0.0112 \pm 0.0046 \mu \mathrm{M}$ at low ATP $(10 \mu \mathrm{M})$ and $0.02 \pm 0.013 \mu \mathrm{M}$ at high ATP $(1 \mathrm{mM})$ concentrations (Table 1). For cellular inhibition of MPS1, we evaluated the effect of the inhibitor on MPS1 autophosphorylation at the activation site T676, and the N-terminal sites T33/S37 in human colon cancer HCT116 cells (Figure 1B). CCT271850 potently inhibited phosphorylation of ectopically expressed MPS1 at both sites in a dose-dependent manner (Figure 1B). The decrease in phosphorylation was accompanied by corresponding increase in mobility of total MPS1 in SDS-PAGE - another measure of the decrease in MPS1 phosphorylation (Figure 1B, lower panel).

The N-terminal phosphorylation sites of the MPS1 protein have previously been identified as autophosphorylation sites through mass spectrometry of in vitro as well as in vivo phosphorylated MPS1 protein (Jelluma et al, 2008; Xu et al, 2009). Here we used phospho-MPS1 pThr33/pSer37 antibody (pT33pS37) to demonstrate recombinant MPS1 is indeed autophosphorylated at these sites in an in vitro kinase assay (Supplementary Figure S1A). This autophosphorylation was previously suggested to be inhibited by the MPS1 inhibitor AZ3146; however, it has not been demonstrated (Hewitt et al, 2010). The lack of phosphorylation on MPS1 T33A and S37A mutants confirmed the specificity of the antibodies (Supplementary Figure S1C). We were also able to detect phosphorylation of the endogenous MPS1 T33S37 in immunoprecipitation assays following nocodazole-mediated mitotic arrest of HCT116 cells and treatment with CCT271850 in the presence of the proteasome inhibitor MG132 to block mitotic abrogation (Figure 1C), as well as when using the previously reported MPS1 inhibitor, CCT251455 (Naud et al, 2013; Supplementary Figure S1B). MPS1 phosphorylation was strongly induced upon nocodazole-mediated mitotic arrest and was completely inhibited by treatment of arrested cells with CCT271850. In addition, phosphorylation of the endogenous MPS1 at T33/S37 sites in mitotic cells and its inhibition by CCT271850 were demonstrated by immunofluorescence using pT33pS37 antibodies (Figure 1D). pT33pS37 staining was co-localized with ACA at kinetochores, but was completely lost upon treatment with CCT271850. To quantitatively measure MPS1 autophosphorylation in cells at the T33/S37 sites, we optimised an electrochemiluminescence (Meso Scale Discovery, MSD) assay (Naud et al, 2013). Using this approach we showed that CCT271850 potently inhibited MPS1 T33/S37 phosphorylation with $\mathrm{IC}_{50}$ value of $0.059 \pm 0.022 \mu \mathrm{M}$ (Table 1). Furthermore, we showed that treatment of nocodazolearrested HCT116 cells with CCT271850 caused SAC abrogation as measured by inhibition of the histone $\mathrm{H} 3$ phosphorylation at S10 with an $\mathrm{IC}_{50}$ value of $0.067 \pm 0.004 \mu \mathrm{M}$ (Table 1). Moreover, when compared side-by-side with NMS-P715, CCT271850 was approximately eight-fold more potent (Supplementary Figure S1D).

Effects of CCT271850 on the activation of SAC and the cell cycle. The SAC ensures accurate chromosomal segregation by delaying the onset of anaphase until all chromosomes are properly attached to the spindle poles (Lara-Gonzalez et al, 2012). MPS1 activity is required for activation of the SAC (Kang et al, 2007) and inhibition of its activity results in SAC over-ride and missegregation of chromosomes (Colombo et al, 2010; Tardif et al, 2011). HeLa cells treated with CCT271850 showed an early exit from mitosis (Figure 2A). Cells treated with $0.3 \mu \mathrm{m}$ of CCT271850 spent, on average, $12 \mathrm{~min}$ to pass from nuclear envelope breakdown to the onset of anaphase, compared to $57 \mathrm{~min}$ for the untreated control cells (Figure 2A). The observed SAC abrogation resulted in a large percentage of cells undergoing cell division with unaligned 

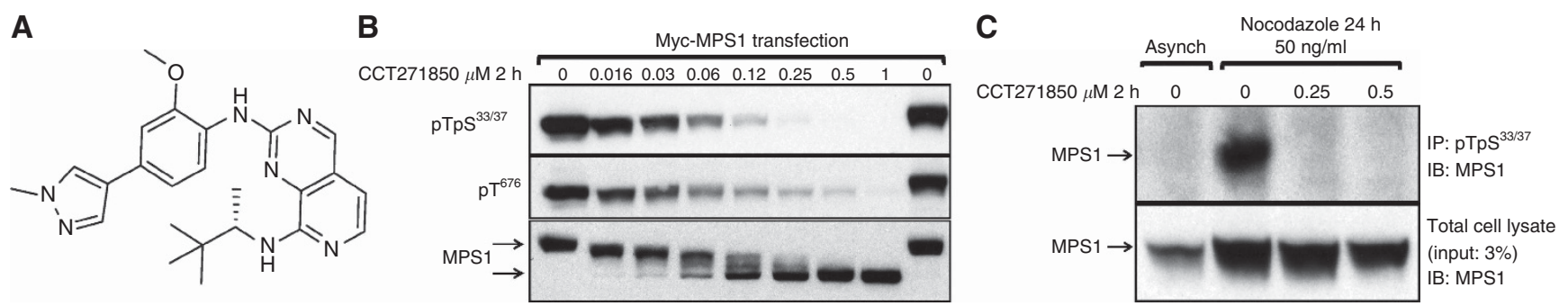

D

DAPI
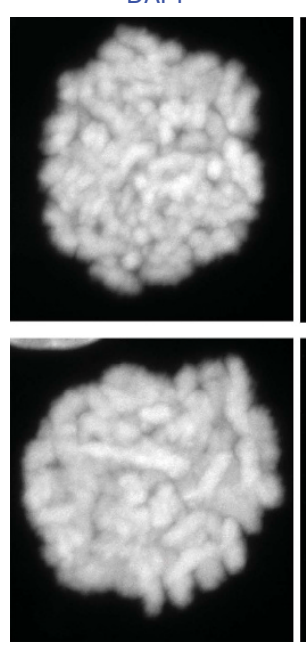

ACA
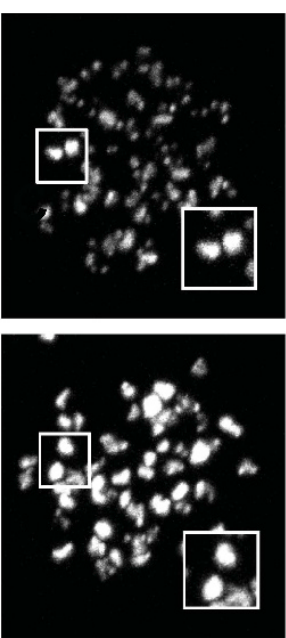

$\mathrm{pTpS}^{33 / 37}$
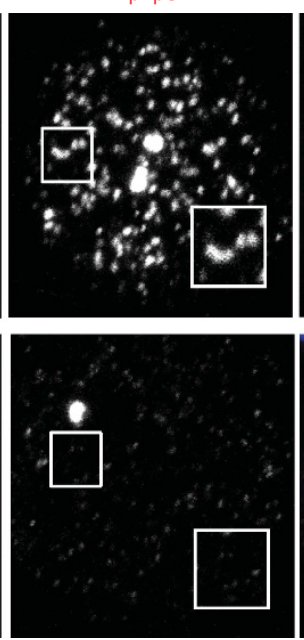

Merged

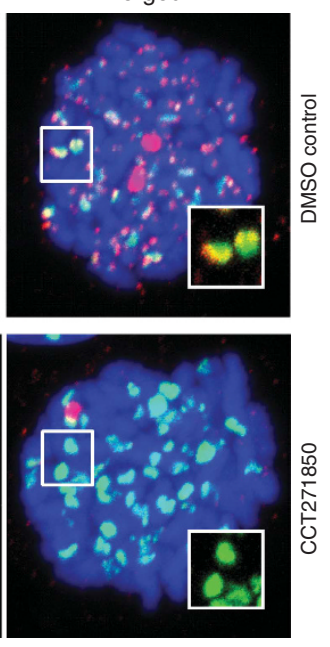

Figure 1. CCT271850 inhibits MPS1 autophosphorylation in cells. (A) Structure of CCT271850. (B) HCT116 cells transiently expressing Myc-tagged MPS1 were treated with increasing concentrations of CCT271850 for $2 \mathrm{~h}$. Cell lysates were analysed for MPS1 autophosphorylation (at pT33pS37 and pT676 sites) and gel shift using immunoblotting. (C) HCT116 cells were synchronised with nocodazole for $24 \mathrm{~h}$ followed by treatment with indicated concentrations of CCT271850 for $2 \mathrm{~h}$ in the presence of MG132. Cell lysates were immunoprecipitated for endogenous MPS1 with phospho-specific anti-pT33pS37 antibodies and immunoblotted with anti-MPS1 antibodies. Total cell lysates were also immunoblotted with anti-MPS1 antibodies as a control for immunoprecipitation input (lower panel). (D) Immunofluorescence for MPS1 pT33pS37 localisation at kinetochores with and without treatment with CCT271850. Cells were treated with CCT271850 for $1 \mathrm{~h}$, followed by treatment with nocodazole, MG132 and СCT271850 for an additional hour. Cells were fixed and stained as indicated.

Table 1. IC $\mathrm{C}_{50}$ of CCT271850 in in vitro and cell-based assays

\begin{tabular}{|l|c|}
\hline & CCT271850 ( $\mu \mathrm{M})$ \\
\hline MPS1 IC 50 : Caliper $10 \mu \mathrm{m} \mathrm{ATP}$ & $0.011 \pm 0.004$ \\
\hline MPS1 IC 50 : Caliper $1 \mathrm{~mm}$ ATP & $0.02 \pm 0.013$ \\
\hline MSD HCT116 IC ${ }_{50}$ & $0.059 \pm 0.022$ \\
\hline P-histone H3 IC 50 & $0.067 \pm 0.004$ \\
\hline 3 Days MTT HCT116 IC 50 & $0.151 \pm 0.006$ \\
\hline Abbreviations: IC $C_{50}=$ half maximal inhibitory concentration; MSD $=$ meso scale discovery; \\
MTT =3-(4,5-dimethylthiazol-2-YI)-2,5-diphenyltetrazolium bromide. \\
\hline
\end{tabular}

chromosomes, resulting in aneuploidy and a loss of cell cycle profiles by flow cytometry (Figure $2 \mathrm{~B}$ and $\mathrm{C}$ ). It is known that MPS1 activity is required for recruitment of spindle checkpoint proteins to kinetochores (London and Biggins, 2014). We therefore tested the recruitment of Mad1, Mad2 and BubR1 to the unattached kinetochores (Hewitt et al, 2010; Sliedrecht et al, 2010) after treatment of HeLa cells with CCT271850. The results showed that Mad1, Mad2 and BubR1 levels were abolished at the unattached kinetochores (Figure 2D and E and Supplementary Figure S2A), whereas Zwint-1 levels remain unchanged (Supplementary Figure S2B).

MPS1 inhibition by CCT271850 sensitises selectively MSI + colon cancer and basal breast cancer cell lines to cell death. We further investigated the cellular effect of CCT271850 on asynchronous HCT116 cells. Cells were treated with different concentrations of CCT271850 for 24, 48 and $72 \mathrm{~h}$ and inhibition of histone $\mathrm{H} 3$ phosphorylation and PARP cleavage was examined by immunoblotting. As shown in Figure $3 \mathrm{~A}$, histone $\mathrm{H} 3$ phosphorylation at $\mathrm{S} 10$ was increasingly inhibited in a time-dependent manner by all three concentrations of the compound. Induction of apoptotic cell death upon CCT271850 treatment also increased in a timedependent manner as determined by the levels of cleaved PARP. A marked increase on p53 levels in HCT116 cells upon treatment with CCT271850 for 24 and $48 \mathrm{~h}$ is consistent with induced p53 response due to aneuploidy (Tardif et al, 2011). Treatment with CCT271850 for 24 and $48 \mathrm{~h}$ also resulted in a reduction of MPS1 protein levels, indicating mitotic exit (Cui et al, 2010).

We have recently generated HCT116 and DLD1 cell lines resistant to a variety of MPS1 inhibitors due to specific point mutations in MPS1 kinase domain (Gurden et al, 2015). To determine whether the cellular effects seen upon CCT271850 treatment in Figure 3A were selectively caused by MPS1 inhibition (Figure 3A), we used the AZR1-resistant HCT116 cells carrying the MPS1 S611G mutation, as a model. As shown in Figure 3B, inhibition of histone H3 phosphorylation by CCT271850 in AZR1 cells was abolished compared with the parental HCT116 cells. Similarly, PARP cleavage upon CCT271850 treatment was significantly reduced in AZR1 cell line, indicating that the apoptotic cell death induced by CCT271850 is mediated by MPS1 inhibition. Inhibition of P-histone $\mathrm{H} 3$ and PARP cleavage by CCT271850 in AZR1 cell lines was seen only at higher 

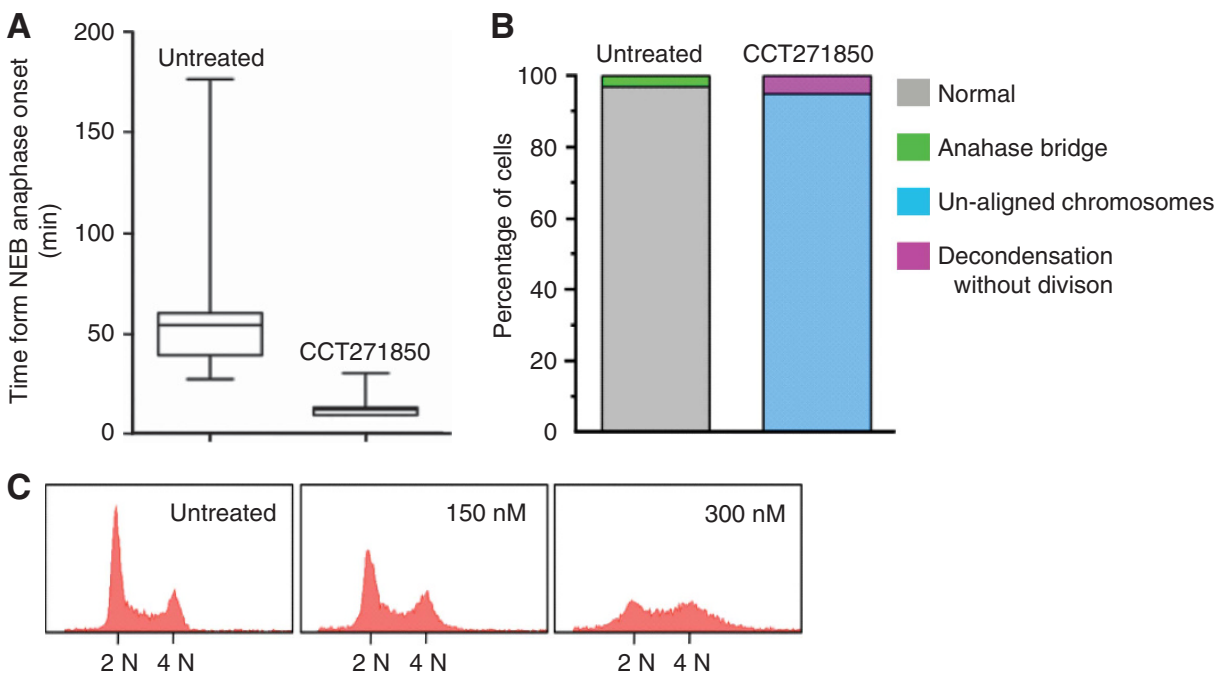

D

DAPI

ACA
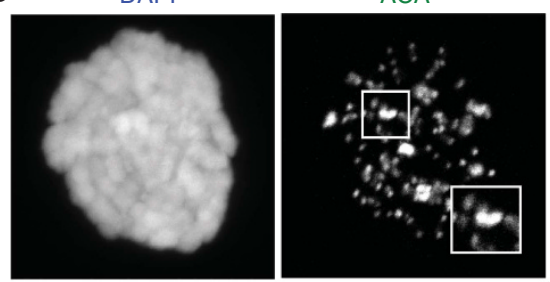

Mad1

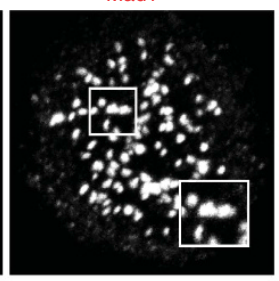

Merged
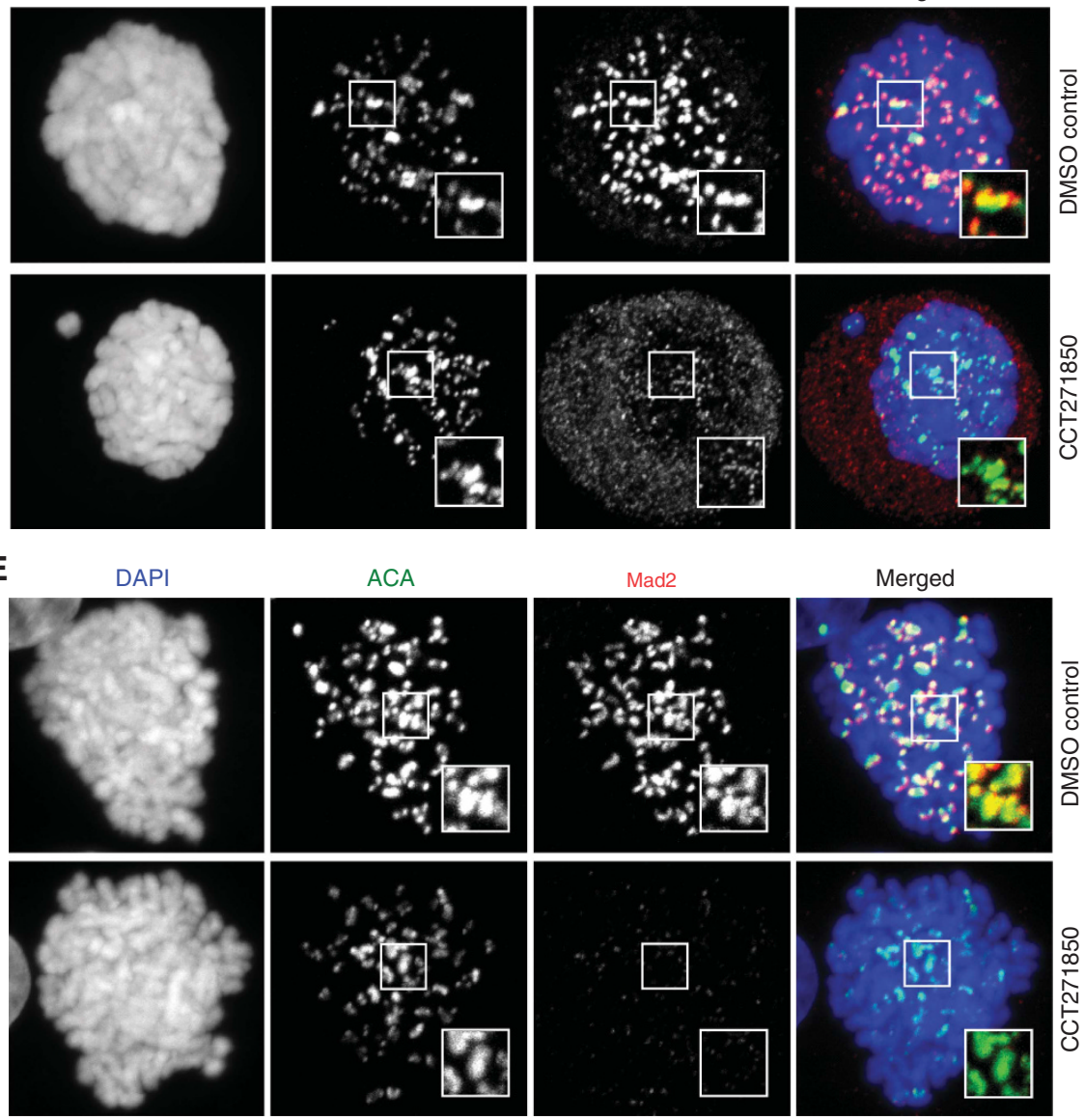

Figure 2. Mitotic defects in cells treated with CCT271850. (A) Time from nuclear envelope breakdown to anaphase onset in asynchronous HeLa cells stably expressing Histone H2B-mCherry was measured using time-lapse microscopy in the presence or absence of $0.3 \mu \mathrm{M}$ of CCT271850. Images were taken every 3 min for $24 \mathrm{~h}$. (B) Quantification of mitotic defects of HeLa cells from A. (C) Cell cycle analysis of HCT116 cells treated with the indicated concentrations of CCT271850 for $24 \mathrm{~h}$. (D, E) Immunofluorescence for Mad1 and Mad2 localisation at kinetochores with and without treatment with CCT271850. Cells were treated with CСT271850 for $1 \mathrm{~h}$, followed by treatment with nocodazole, MG132 and CCT271850 for an additional hour. Cells were fixed and stained as indicated.

concentrations of CCT271850 $(\geqslant 1 \mu \mathrm{M} ;$ Figure $3 \mathrm{~B}$ and Supplementary Figure S3).

To evaluate CCT271850 antiproliferation effects in a large panel of human cancer cell lines, 91 cell lines were treated for $72 \mathrm{~h}$ and 14 days at different compound concentrations in growth inhibition assays. The growth inhibition values as measured by $\mathrm{IC}_{50}$ are summarised in Table 2 and Supplementary Table S1. In summary, at $72 \mathrm{~h}$ of CCT271850 treatment, more than half the cell lines (57/91) showed $\mathrm{IC}_{50}$ values below the average of $1.588 \mu \mathrm{M}$, and nearly half (45/91) showed an $\mathrm{IC}_{50}$ at submicromolar values. Cell lines from colon and head and neck cancers were among the most sensitive. Importantly, microsatellite instability-positive $(\mathrm{MSI}+)$ colon cancer cell lines were more sensitive to cell death by CCT271850 in comparison to microsatellite stable (MSS) cell lines 

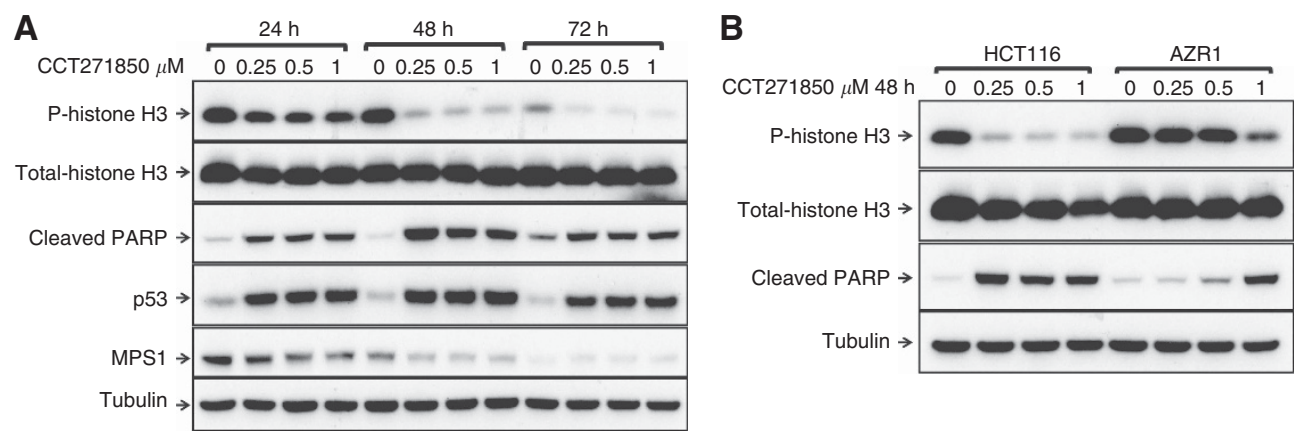

Figure 3. Biomarker modulation and antiproliferative effects of CCT271850. (A) Time course of biomarker modulation by CCT271850 in HCT116 cells. Cells were treated with indicated concentrations of the inhibitor for 24,48 and $72 \mathrm{~h}$. Cell lysates were analysed by immunoblotting for inhibition of histone $\mathrm{H} 3$ phosphorylation at S10, induction of p53 and PARP cleavage. Total histone H3 and alpha-tubulin were used as loading controls. (B) Biomarker modulation by CCT271850 is reversed in AZR1 cell line expressing an inhibitor-resistant mutant of MPS1. HCT116 WT and AZR1-resistant cell lines were treated with indicated concentrations of CCT271850 for $48 \mathrm{~h}$ and analysed for inhibition of histone H3 and PARP cleavage as described above.

(average $\mathrm{IC}_{50}$ at $72 \mathrm{~h}: \mathrm{MSI}+=0.276 \pm 0.06, \mathrm{MSS}=1.31 \pm 0.06$ $P=0.03$; Table 2). In addition, in a panel of 20 breast cancer cell lines, we found that the basal, as well as specifically the PTENdeficient basal cancer cells, were more sensitive to cell death by CCT271850 in comparison to luminal breast cancer cell lines (average $\mathrm{IC}_{50}$ at $96 \mathrm{~h}:$ Basal $=0.7 \pm 0.2, \quad$ Luminal $=2.1 \pm 0.54$; $P=0.014$; Table 2).

Development of PD biomarker assay for measuring direct inhibition of MPS1 in xenograft tumours. The indirect readout of the inhibition of histone $\mathrm{H} 3$ phosphorylation at S10 has been widely used as a biomarker for inhibition of MPS1 (Colombo et al, 2010; Kwiatkowski et al, 2010; Santaguida et al, 2010; Tardif et al, 2011). Mitotic exit following MPS1 inhibition leads to a robust reduction in histone $\mathrm{H} 3$ phosphorylation. Similar modulation of other mitotic markers such as cyclin B levels has also been shown in response to MPS1 inhibition (Colombo et al, 2010; Tardif et al, 2011). Although direct inhibition of MPS1 autophosphorylation using phospho-specific antibodies has been reported in cells (Sliedrecht et al, 2010; Tardif et al, 2011), such inhibition has never been demonstrated in ex vivo tumour samples. In addition, although a direct inhibition of phosphorylation of the natural substrate of MPS1, KNL1, by MPS1 inhibitors has been described using immunohistochemistry (Maia et al, 2015), this method it is not as quantitative as an ELISA-type method such as MSD assay. To directly measure MPS1 inhibition using CCT271850 in a quantitative method, we have recently generated stable DLD1 cell line clones where GFP-MPS1 is overexpressed in a Dox-inducible manner (Gurden et al, 2015). To measure autophosphorylation of MPS1 in vivo, we subcutaneously injected DLD1-GFP-MPS1 cells into mice to establish xenograft tumours that express ectopic MPS1 upon induction by Dox. Despite the levels of GFP-MPS1 being only 1.5-fold higher compared to endogenous MPS1 (band intensity of GFP-MPS1 vs endogenous MPS1; Figure 4A), the signal for MPS1 autophosphorylation at T33/S37 in MSD assay was robustly increased in DOX-induced tumours, compared to the non-induced tumours (Figure 4B). The expression of GFP-MPS1 in these tumour samples was also confirmed by the MSD assay in a $\mathrm{PK} / \mathrm{PD}$ study conducted with CCT271850 compound in the inducible DLD1 xenograft tumour (Figure 4C). Importantly, at 2, 6 and $12 \mathrm{~h}$ after a single dose of $100 \mathrm{mg} / \mathrm{kg}$ of CCT271850, there was $>90 \%$ inhibition of MPS1 autophosphorylation, which dropped to $79 \%$ at $24 \mathrm{~h}$ (Figure $4 \mathrm{D}$ ). When a single dose of $50 \mathrm{mg} / \mathrm{kg}$ of CCT271850 was used, the inhibition ranged from $\sim 89 \%$ at 2 and $6 \mathrm{~h}$, to $61 \%$ at $24 \mathrm{~h}$ after treatment. At $12 \mathrm{~h}, 50$ and $100 \mathrm{mg} / \mathrm{kg}$ dosing of inhibitor caused $90 \%$ and $78 \%$ reduction in MPS1 phosphorylation respectively. When analysing the tumour compound concentration, we found that concentration of CCT271850 in the tumours was $>1 \mu \mathrm{M}$ at all time points, which is significantly higher than the IC $_{50}$ value of CCT271850 in DLD1 cells $(396 \mathrm{~nm}$; Figure 4E). The plasma concentration of CCT271850 was comparable at 2 and $6 \mathrm{~h}$ time points but gradually decreased at 12 and $24 \mathrm{~h}$ (Figure 4F). The greatest drop in inhibition of MPS1 phosphorylation was observed for $50 \mathrm{mg} / \mathrm{kg}$ at $24 \mathrm{~h}$, which correlated with the lowest levels of the compound in both plasma and tumour. Similar results were obtained when $100 \mathrm{mg} / \mathrm{kg}$ of CCT251455, our first published MPS1 inhibitor (Naud et al, 2013), were dosed in mice bearing Dox-induced DLD1 xenografts. Autophosphorylation of MPS1 at the T33/S37 sites was completely inhibited in tumours collected at 2 and $6 \mathrm{~h}$ after treatment, whereas the levels of MPS1 overexpression (GFP) measured by MSD assays were similar in all treated and control samples (Supplementary Figure S4).

Efficacy of CCT271850 in HCT116 xenografts. We then examined the efficacy of CCT271850 in vivo using HCT116 tumour xenografts. Mice bearing tumour xenografts were dosed twice daily with 50 or $100 \mathrm{mg} / \mathrm{kg}$ of CCT271850 for days $0-7$ and $12-15$. Moderate level of efficacy at the dose of $100 \mathrm{mg} / \mathrm{kg}$ was achieved with tumour $v s$ control $(\mathrm{T} / \mathrm{C})$ of $60 \%$ based on the final tumour volume (Figure 5A). Treatment with CCT271850 was well tolerated in both rounds of dosing with less than $8 \%$ body weight loss compared with the vehicle-treated controls over 15 days (Figure 5B). While this T/C is still modest, it has been shown in the literature that only moderate efficacy can be achieved in mouse models with tolerated doses of MPS1 inhibitors as single agent in the models that have been tested (Colombo et al, 2010; Tardif et al, 2011; Laufer et al, 2014; Kusakabe et al, 2015; Maia et al, 2015), indicating that combination studies with standard-of-care may lead to a more successful use of MPS1 inhibitors in clinic in this particular type of cancer.

\section{DISCUSSION}

Mitosis has attracted a large number of studies focusing on cancer for decades - either to identify mitotic mechanisms involved in cancer, or at a translational level, to target fast proliferating cancer cells using antimitotic drugs. There is no doubt that antimitotics are a success in certain types of cancer, but the lack of differentiation between normal and cancer cells underlines their limitations in clinic. Mitotic kinases have been identified as essential proteins in regulating mitosis and therefore they have represented an attractive target in cancer therapy during the past two decades. 
Table 2. IC 50 of CCT271850 determined by MTT and clonogenic assays (CA)

\begin{tabular}{|c|c|c|c|c|c|}
\hline \multicolumn{2}{|l|}{ Cell line } & MSI/MSS & 3-Day MTT ( $\mu \mathrm{M})$ & & 14-Day CA $(\mu \mathrm{m})$ \\
\hline \multicolumn{2}{|l|}{ SW620 } & MSS & \multicolumn{2}{|c|}{0.065} & 0.02 \\
\hline \multicolumn{2}{|l|}{ HCT-15 } & $\mathrm{MSI}$ & \multicolumn{2}{|l|}{0.102} & 0.042 \\
\hline \multicolumn{2}{|l|}{ HCT116 } & $\mathrm{MSI}$ & \multicolumn{2}{|l|}{0.149} & 0.0226 \\
\hline \multicolumn{2}{|l|}{ SW48 } & MSS & \multicolumn{2}{|l|}{0.171} & 0.037 \\
\hline MAWI & & ND & 0.172 & & 0.051 \\
\hline COLO205 & & MSS & 0.284 & & 0.016 \\
\hline PC/JW2 & & ND & 0.286 & & 0.036 \\
\hline LS174T & & $\mathrm{MSI}$ & 0.306 & & 0.037 \\
\hline RKO & & MSI & 0.341 & & 0.06 \\
\hline DLD1 & & $\mathrm{MSI}$ & 0.396 & & 0.041 \\
\hline SW403 & & MSS & 1.031 & & 0.009 \\
\hline HT-29 & & MSS & 1.124 & & 0.07 \\
\hline COLO741 & & MSS & 1.542 & & 0.022 \\
\hline COLO320 & & MSS & 1.752 & & 0.078 \\
\hline SW480 & & MSS & 1.838 & & 0.044 \\
\hline SW1417 & & MSS & 2.798 & & 0.107 \\
\hline HT55 & & MSS & 2.923 & & 0.024 \\
\hline SW837 & & MSS & 3.258 & & 0.07 \\
\hline SNU-C2B & & $\mathrm{MSI}$ & $>100$ & & 0.059 \\
\hline EFM-19 & Luminal & WT & 1.23 & 0.473 & 0.044 \\
\hline HS578T & Basal B & WT & 8.772 & 0.832 & 0.042 \\
\hline HCC1143 & Basal A & WT & 2.59 & 0.957 & 0.093 \\
\hline MDA-MB-157 & Basal B & WT & 5.392 & 1.131 & 0.059 \\
\hline MCF7 & Luminal B & WT & 2.377 & 1.146 & 0.011 \\
\hline KPL-1 & Luminal & WT & 2.215 & 1.266 & ND \\
\hline BT20 & Basal A & WT & 2.67 & 1.613 & 0.037 \\
\hline MDA-MB-231 & Basal B & WT & 7.945 & 1.706 & 0.053 \\
\hline ZR75.1 & Luminal B & Null & 2.999 & 1.733 & 0.04 \\
\hline HCC1428 & Luminal B & WT & 1.03 & 1.784 & ND \\
\hline T47D & Luminal B & WT & 2.02 & 2.183 & 0.065 \\
\hline MDA-MB-361 & Luminal & WT & 0.705 & 3.238 & ND \\
\hline CAMA1 & Luminal & WT & 7.157 & 4.01 & 0.036 \\
\hline MDA-MB-453 & Luminal B & WT & 2.21 & 5.67 & ND \\
\hline
\end{tabular}

MPS1 is an essential kinase in initiating the SAC, which, in cooperation with Aurora-B kinase that predominantly maintains SAC signalling (Gurden et al, 2016), represents the cornerstone of this surveillance mechanism. MPS1 has been found to be deregulated in a variety of human cancers and has been associated with certain genetic abnormalities characterised in tumour cells, including chromosomal instability (Carter et al, 2006) and aneuploidy (Brough et al, 2011; Gordon et al, 2012). RNAimediated knockdown or chemical inhibition of MPS1 has also been shown to mediate cell death in PTEN-deficient breast tumour cells (Brough et al, 2011). Therefore, MPS1 has been brought to the attention as anticancer target. 
A

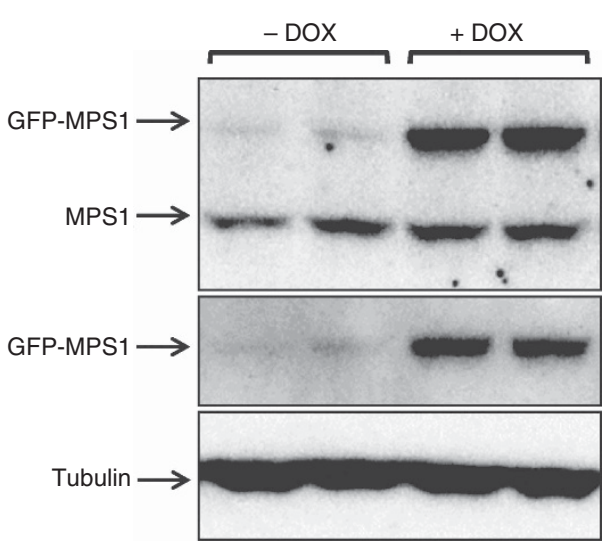

C 1500

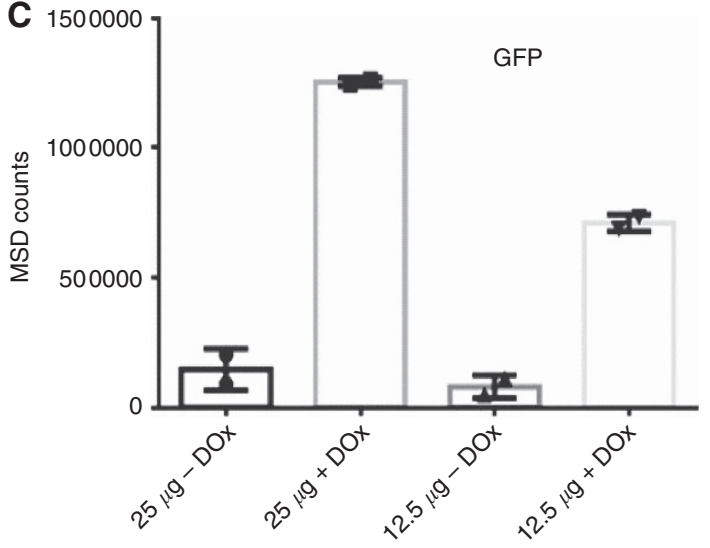

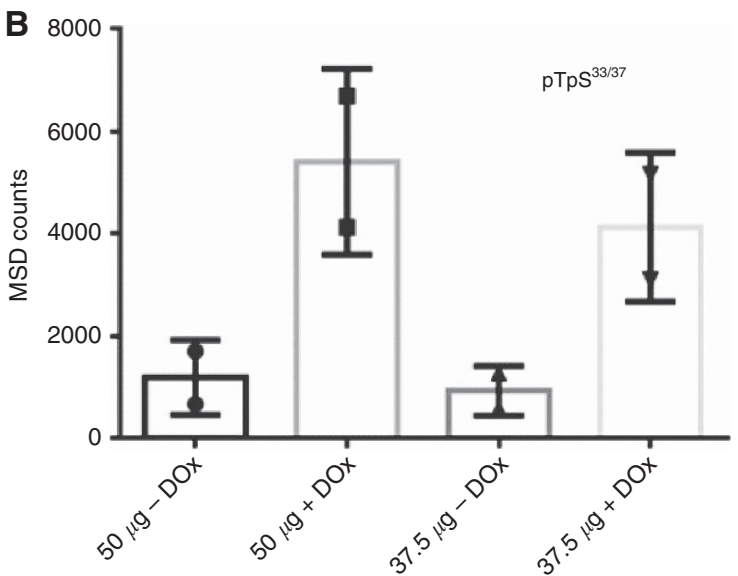

D
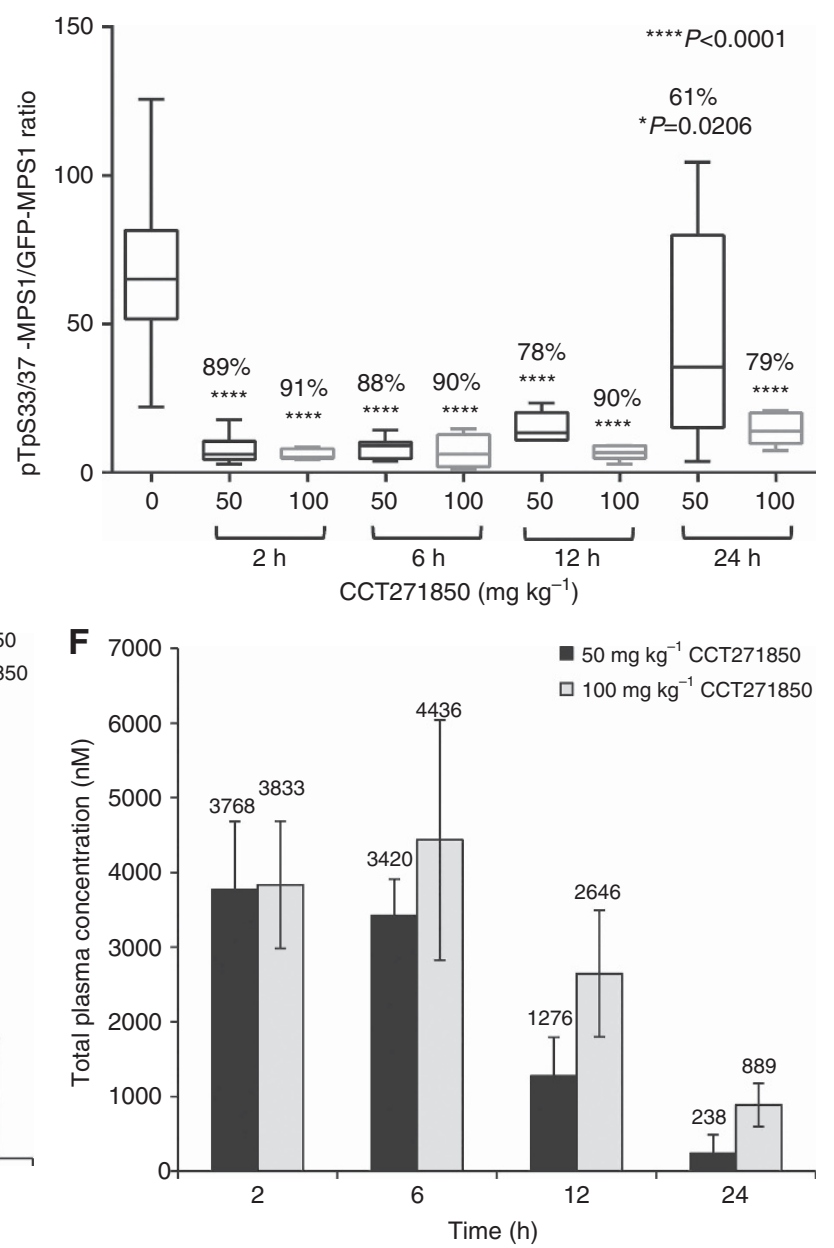

Figure 4. Development of a PD biomarker assay for measuring direct inhibition of MPS1 in DLD1 GFP-MPS1 Dox-inducible xenografts. (A) Five million DLD1 cells, stably expressing Dox-inducible GFP-MPS1, were used to grow tumours in athymic mice. Mice were dosed with $\sim 6$ mg of Dox per day for 3 days. Tumours were lysed and equal amount of protein was used for immunoblotting with GFP and MPS1 antibodies. (B) MSD assay for detection of MPS1 phosphorylation in xenograft tumours. Cell lysates $(37.5$ and $50 \mu \mathrm{g})$ from non-induced and induced tumours were used for MSD assay with $\mathrm{PTpS}^{33 / 37}$ antibodies. (C) Two concentrations (12.5 and $\left.25 \mu \mathrm{g}\right)$ of cell lysates were also used for MSD with GFP antibodies. (D) PK/PD studies in DLD1 GFP-MPS1 Dox-inducible xenografts treated with CCT271850. Mice bearing bilateral DLD1 (GFP-MPS1 Dox inducible) xenografts were placed on Dox diet for 3 days ( $\sim 6 \mathrm{mg} /$ day). Twenty-four hours prior to harvest, mice were given a single $10 \mathrm{mg}$ oral gavage bolus of Dox, followed by a single dose of 50 or $100 \mathrm{mg} / \mathrm{kg}$ of CCT271850. Tumours and plasma samples were collected at 2,6, 12 and $24 \mathrm{~h}$ after

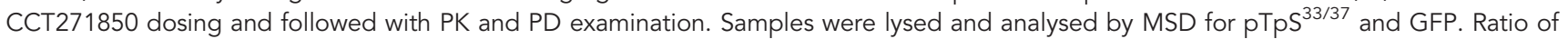
phospho-MPS1 (pTpS ${ }^{33 / 37}$ )/Total-MPS1 (GFP) in tumour samples at various time points after 50 and $100 \mathrm{mg} / \mathrm{kg}$ CCT271850 dosing was calculated. Concentration of CCT271850 in tumours $(E)$ and plasma $(F)$ was measured. 

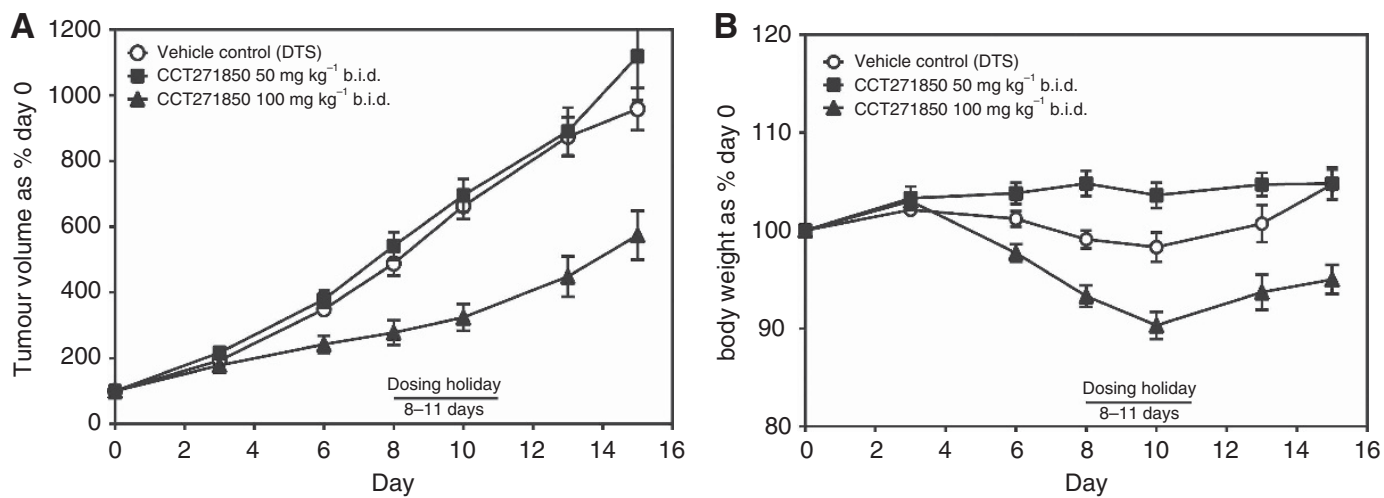

Figure 5. Efficacy of CCT271850 in HCT116 xenografts. Athymic mice bearing HCT116 tumours were dosed with vehicle, 50 or $100 \mathrm{mg} / \mathrm{kg}$ of CCT271850 orally twice daily (b.i.d) with a break after 1 week's dosing for days $0-7$ and 12-15. (A) The mean tumour volumes \pm s.e.m. for control and CCT271850-treated mice were measured at different days throughout the experiment. (B) Body weights for treated and control mice were measured.

Here we present the discovery of CCT271850, a novel, oral, potent and selective MPS1 inhibitor in biochemical and cellular assays, with in vivo activity. CCT271850-induced growth inhibition was observed in a wide range of cancer cell lines. The highest sensitivity was observed in colon cancer cell lines, particularly the MSI-positive colon cancer cell lines in comparison to MSS. In addition, basal breast cancer cell lines, some of which are also PTEN-deficient, showed higher sensitivity to cell death upon MPS1 inhibition in comparison to luminal breast cancers, indicating a potential patient stratification for treatment with an MPS1 inhibitor. Consistent with MPS1 inhibition, CCT271850-treated cells lost kinetochore localisation of the checkpoint proteins BUBR1, MAD1 and MAD2, spent less time in mitosis compared to untreated cells, underwent an abnormal division with unaligned chromosomes, which caused aneuploidy and cell death. We have previously shown that following MPS1 inhibition, the majority of the cells die after one or two mitoses (Gurden et al, 2016), indicating a distinct difference between MPS1 inhibitors in comparison to other mitotic kinase inhibitors such as Aurora and Polo-like kinase inhibitors; these inhibitors require multiple cell cycles to induce cell killing, and thus have a narrower therapeutic window in clinic (Bavetsias, Linardopoulos, 2015). These effects of CCT2571850 were specifically caused through MPS1 since cell lines, previously generated (Gurden et al, 2015), containing a S611G mutation in MPS1 were resistant to inhibition.

The lack of a direct, quantitative biomarker for MPS1 inhibition in order to identify a PD vs efficacy relationship prompted us to set up and optimise an inducible MPS1 model in DLD1 colon cancer cells, in order to directly measure MPS1 inhibition via MPS1 autophosphorylation. Assays using MSD have been proved to be very sensitive and quantitative in vitro and in vivo. We validated and characterised the specificity of a commercially available T33/ S37 anti-MPS1 phospho-antibody, which we used to analyse MPS1 activity in biochemical assays, in cell and in vivo. We showed that $100 \mathrm{mg} / \mathrm{kg}$ of CCT271850 is sufficient to inhibit MPS1, in vivo, for at least $24 \mathrm{~h}$ in HCT116 human tumour xenografts, by $\sim 80 \%$, as shown by a decrease in MPS1 autophosphorylation levels. This level of inhibition resulted in a moderate effect on tumour growth, suggesting that higher, more sustained target inhibition may be required for a more robust tumour response. Likewise, although $50 \mathrm{mg} / \mathrm{kg}$ showed robust target inhibition for up to $12 \mathrm{~h}$, this was insufficient to produce any reduction in tumour volume. However, since higher dosing regiments are limited by animal toxicity, a single agent administration may not be as efficacious as is required in clinical settings in the type of cancer models tested. This suggests that changing direction towards using MPS1 inhibitors in combination with standard-of-care drugs, for example, with taxanes, may be a more beneficial approach for the clinic. It has been recently shown that paclitaxel induces multipolar spindles and mitotic delay (Zasadil et al, 2014). Our hypothesis is that MPS1 inhibition will induce abrogation of paclitaxel-induced mitotic delay causing gross chromosomal abnormalities and massive cell death in cancer cells.

\section{ACKNOWLEDGEMENTS}

This work was supported by Cancer Research UK (grant number C309/A11566) and Breast Cancer Now (grant ref: CTR-Q3). We also acknowledge the CRT Pioneer Fund and Sixth Element Capital for funding (to SJA and PI) and NHS funding to the NIHR Biomedical Research Centre.

${ }^{3}$ Present address: Lahore University of Management Sciences, D.H.A. Lahore Cantt. 54792, Lahore, Pakistan.

${ }^{4}$ Present address: i3S-Instituto de Investigação e Inovação em Saúde da Universidade do Porto, Rua Alfredo Allen 208, Porto 4200-135, Portugal.

${ }^{5}$ Present address: Phenex Pharmaceuticals, 67059 Ludwigshafen am Rhein, Germany.

\section{CONFLICT OF INTEREST}

All authors are employees of The Institute of Cancer Research, which has a commercial interest in drug development programmes (see www.icr.ac.uk). Please note that all authors who are, or have been, employed by The Institute of Cancer Research are subject to a 'Rewards to Inventors Scheme', which may reward contributors to a programme that is subsequently licensed.

\section{REFERENCES}

Bavetsias V, Linardopoulos S (2015) Aurora kinase inhibitors: current status and outlook. Front Oncol 5: 278.

Brough R, Frankum JR, Sims D, Mackay A, Mendes-Pereira AM, Bajrami I, Costa-Cabral S, Rafiq R, Ahmad AS, Cerone MA, Natrajan R, Sharpe R, Shiu KK, Wetterskog D, Dedes KJ, Lambros MB, Rawjee T, Linardopoulos S, Reis-Filho JS, Turner NC, Lord CJ, Ashworth A (2011) Functional viability profiles of breast cancer. Cancer Discov 1(3): 260-273.

Carter SL, Eklund AC, Kohane IS, Harris LN, Szallasi Z (2006) A signature of chromosomal instability inferred from gene expression profiles predicts clinical outcome in multiple human cancers. Nat Genet 38(9): 1043-1048. Colombo R, Caldarelli M, Mennecozzi M, Giorgini ML, Sola F, Cappella P, Perrera C, Depaolini SR, Rusconi L, Cucchi U, Avanzi N, Bertrand JA, 
Bossi RT, Pesenti E, Galvani A, Isacchi A, Colotta F, Donati D, Moll J (2010) Targeting the mitotic checkpoint for cancer therapy with NMSP715, an inhibitor of MPS1 kinase. Cancer Res 70(24): 10255-10264.

Cui Y, Cheng X, Zhang C, Zhang Y, Li S, Wang C, Guadagno TM (2010) Degradation of the human mitotic checkpoint kinase Mps1 is cell cycleregulated by APC-cCdc20 and APC-cCdh1 ubiquitin ligases. J Biol Chem 285(43): 32988-32998.

Daniel J, Coulter J, Woo JH, Wilsbach K, Gabrielson E (2011) High levels of the Mps1 checkpoint protein are protective of aneuploidy in breast cancer cells. Proc Natl Acad Sci USA 108(13): 5384-5389.

Dobles M, Liberal V, Scott ML, Benezra R, Sorger PK (2000) Chromosome missegregation and apoptosis in mice lacking the mitotic checkpoint protein Mad2. Cell 101(6): 635-645.

Foley EA, Kapoor TM (2013) Microtubule attachment and spindle assembly checkpoint signalling at the kinetochore. Nat Rev Mol Cell Biol 14(1): $25-37$.

Gordon DJ, Resio B, Pellman D (2012) Causes and consequences of aneuploidy in cancer. Nat Rev Genet 13(3): 189-203.

Gurden MD, Anderhub SJ, Faisal A, Linardopoulos S (2016) Aurora B prevents premature removal of spindle assembly checkpoint proteins from the kinetochore: a key role for Aurora B in mitosis. Oncotarget doi:0.18632/oncotarget.10657.

Gurden MD, Westwood IM, Faisal A, Naud S, Cheung KM, McAndrew C, Wood A, Schmitt J, Boxall K, Mak G, Workman P, Burke R, Hoelder S, Blagg J, Van Montfort RL, Linardopoulos S (2015) Naturally occurring mutations in the mps1 gene predispose cells to kinase inhibitor drug resistance. Cancer Res 75(16): 3340-3354.

Hewitt L, Tighe A, Santaguida S, White AM, Jones CD, Musacchio A, Green S, Taylor SS (2010) Sustained Mps1 activity is required in mitosis to recruit O-Mad2 to the Mad1-C-Mad2 core complex. J Cell Biol 190(1): 25-34.

Innocenti P, Woodward HL, Solanki S, Naud S, Westwood IM, Cronin N, Hayes A, Roberts J, Henley AT, Baker R, Faisal A, Mak GW-Y, Box G, Valenti M, De Haven Brandon A, O'Fee L, Saville H, Schmitt J, Matijssen B, Burke R, van Montfort RLM, Raynaud FI, Eccles SA, Linardopoulos S, Blagg J, Hoelder S (2016) Rapid discovery of Pyrido[3,4-d]pyrimidine inhibitors of monopolar spindle kinase 1 (MPS1) using a structure-based hybridization approach. J Med Chem 59(8): 3671-3688.

Jelluma N, Brenkman AB, McLeod I, Yates 3rd JR, Cleveland DW, Medema RH, Kops GJ (2008) Chromosomal instability by inefficient Mps1 auto-activation due to a weakened mitotic checkpoint and lagging chromosomes. PLoS One 3(6): e2415.

Jemaa M, Galluzzi L, Kepp O, Senovilla L, Brands M, Boemer U, Koppitz M, Lienau P, Prechtl S, Schulze V, Siemeister G, Wengner AM, Mumberg D, Ziegelbauer K, Abrieu A, Castedo M, Vitale I, Kroemer G (2013) Characterization of novel MPS1 inhibitors with preclinical anticancer activity. Cell death and differentiation 20(11): 1532-1545.

Kang J, Chen Y, Zhao Y, Yu H (2007) Autophosphorylation-dependent activation of human Mps1 is required for the spindle checkpoint. Proc Natl Acad Sci USA 104(51): 20232-20237.

Kops GJ, Foltz DR, Cleveland DW (2004) Lethality to human cancer cells through massive chromosome loss by inhibition of the mitotic checkpoint. Proc Natl Acad Sci USA 101(23): 8699-8704.

Kops GJ, Weaver BA, Cleveland DW (2005) On the road to cancer: aneuploidy and the mitotic checkpoint. Nature reviews Cancer 5(10): 773-785.

Kusakabe K, Ide N, Daigo Y, Itoh T, Yamamoto T, Hashizume H, Nozu K, Yoshida H, Tadano G, Tagashira S, Higashino K, Okano Y, Sato Y, Inoue M, Iguchi M, Kanazawa T, Ishioka Y, Dohi K, Kido Y, Sakamoto S, Ando S, Maeda M, Higaki M, Baba Y, Nakamura Y (2015) Discovery of imidazo [1,2-b]pyridazine derivatives: selective and orally available Mps1 (TTK) kinase inhibitors exhibiting remarkable antiproliferative activity. J Med Chem 58(4): 1760-1775.

Kwiatkowski N, Jelluma N, Filippakopoulos P, Soundararajan M, Manak MS, Kwon M, Choi HG, Sim T, Deveraux QL, Rottmann S, Pellman D, Shah JV, Kops GJ, Knapp S, Gray NS (2010) Small-molecule kinase inhibitors provide insight into Mps1 cell cycle function. Nat Chem Biol 6(5): 359-368.

Lara-Gonzalez P, Westhorpe FG, Taylor SS (2012) The spindle assembly checkpoint. Curr Biol 22(22): R966-R980.

Laufer R, Ng G, Liu Y, Patel NK, Edwards LG, Lang Y, Li SW, Feher M, Awrey DE, Leung G, Beletskaya I, Plotnikova O, Mason JM, Hodgson R, Wei X, Mao G, Luo X, Huang P, Green E, Kiarash R, Lin DC,
Harris-Brandts M, Ban F, Nadeem V, Mak TW, Pan GJ, Qiu W, Chirgadze NY, Pauls HW (2014) Discovery of inhibitors of the mitotic kinase TTK based on N-(3-(3-sulfamoylphenyl)-1H-indazol-5-yl)acetamides and carboxamides. Bioorg Med Chem 22(17): 4968-4997.

Liu X, Winey M (2012) The MPS1 family of protein kinases. Annu Rev Biochem 81: 561-585.

London N, Biggins S (2014) Mad1 kinetochore recruitment by Mps1mediated phosphorylation of Bubl signals the spindle checkpoint. Genes Dev 28(2): 140-152.

Maia AR, de Man J, Boon U, Janssen A, Song JY, Omerzu M, Sterrenburg JG, Prinsen MB, Willemsen-Seegers N, de Roos JA, van Doornmalen AM, Uitdehaag JC, Kops GJ, Jonkers J, Buijsman RC, Zaman GJ, Medema RH (2015) Inhibition of the spindle assembly checkpoint kinase TTK enhances the efficacy of docetaxel in a triple-negative breast cancer model. Ann Oncol 26(10): 2180-2192.

Manchado E, Guillamot M, Malumbres M (2012) Killing cells by targeting mitosis. Cell Death Differ 19(3): 369-377.

Mao Y, Abrieu A, Cleveland DW (2003) Activating and silencing the mitotic checkpoint through CENP-E-dependent activation/inactivation of BubR1. Cell 114(1): 87-98.

Maure JF, Kitamura E, Tanaka TU (2007) Mps1 kinase promotes sisterkinetochore bi-orientation by a tension-dependent mechanism. Curr Biol 17(24): 2175-2182.

Mosmann T (1983) Rapid colorimetric assay for cellular growth and survival: application to proliferation and cytotoxicity assays. J Immunol Methods 65(1-2): 55-63.

Musacchio A, Salmon ED (2007) The spindle-assembly checkpoint in space and time. Nat Rev Mol Cell Biol 8(5): 379-393.

Naud S, Westwood IM, Faisal A, Sheldrake P, Bavetsias V, Atrash B, Cheung KM, Liu M, Hayes A, Schmitt J, Wood A, Choi V, Boxall K, Mak G, Gurden M, Valenti M, de Haven Brandon A, Henley A, Baker R, McAndrew C, Matijssen B, Burke R, Hoelder S, Eccles SA, Raynaud FI, Linardopoulos S, van Montfort RL, Blagg J (2013) Structure-based design of orally bioavailable $1 \mathrm{H}$-pyrrolo[3,2-c]pyridine inhibitors of mitotic kinase monopolar spindle 1 (MPS1). J Med Chem 56(24): 10045-10065.

Orr B, Godek KM, Compton D (2015) Aneuploidy. Curr Biol 25(13): R538-R542.

Salvatore G, Nappi TC, Salerno P, Jiang Y, Garbi C, Ugolini C, Miccoli P, Basolo F, Castellone MD, Cirafici AM, Melillo RM, Fusco A, Bittner ML, Santoro M (2007) A cell proliferation and chromosomal instability signature in anaplastic thyroid carcinoma. Cancer Res 67(21): 10148-10158.

Santaguida S, Tighe A, D’Alise AM, Taylor SS, Musacchio A (2010) Dissecting the role of MPS1 in chromosome biorientation and the spindle checkpoint through the small molecule inhibitor reversine. J Cell Biol 190(1): 73-87.

Santaguida S, Vernieri C, Villa F, Ciliberto A, Musacchio A (2011) Evidence that Aurora B is implicated in spindle checkpoint signalling independently of error correction. EMBO J 30(8): 1508-1519.

Saurin AT, van der Waal MS, Medema RH, Lens SM, Kops GJ (2011) Aurora B potentiates Mps1 activation to ensure rapid checkpoint establishment at the onset of mitosis. Nat Commun 2: 316.

Schmidt M, Budirahardja Y, Klompmaker R, Medema RH (2005) Ablation of the spindle assembly checkpoint by a compound targeting Mps1. EMBO Rep 6(9): 866-872.

Slee RB, Grimes BR, Bansal R, Gore J, Blackburn C, Brown L, Gasaway R, Jeong J, Victorino J, March KL, Colombo R, Herbert BS, Korc M (2014) Selective inhibition of pancreatic ductal adenocarcinoma cell growth by the mitotic MPS1 kinase inhibitor NMS-P715. Mol Cancer Ther 13(2): 307-315.

Sliedrecht T, Zhang C, Shokat KM, Kops GJ (2010) Chemical genetic inhibition of Mps1 in stable human cell lines reveals novel aspects of Mps1 function in mitosis. PLoS One 5(4): e10251.

Tannous BA, Kerami M, Van der Stoop PM, Kwiatkowski N, Wang J, Zhou W, Kessler AF, Lewandrowski G, Hiddingh L, Sol N, Lagerweij T, Wedekind L, Niers JM, Barazas M, Nilsson RJ, Geerts D, De Witt Hamer PC, Hagemann C, Vandertop WP, Van Tellingen O, Noske DP, Gray NS, Wurdinger T (2013) Effects of the selective MPS1 inhibitor MPS1-IN-3 on glioblastoma sensitivity to antimitotic drugs. J Natl Cancer Inst 105(17): 1322-1331.

Tardif KD, Rogers A, Cassiano J, Roth BL, Cimbora DM, McKinnon R, Peterson A, Douce TB, Robinson R, Dorweiler I, Davis T, Hess MA, Ostanin K, Papac DI, Baichwal V, McAlexander I, Willardsen JA, 
Saunders M, Christophe H, Kumar DV, Wettstein DA, Carlson RO, Williams BL (2011) Characterization of the cellular and antitumor effects of MPI-0479605, a small-molecule inhibitor of the mitotic kinase Mps1. Mol Cancer Ther 10(12): 2267-2275.

Workman P (2003) How much gets there and what does it do?: The need for better pharmacokinetic and pharmacodynamic endpoints in contemporary drug discovery and development. Curr Pharm Design 9(11): 891-902.

Workman P, Aboagye EO, Balkwill F, Balmain A, Bruder G, Chaplin DJ, Double JA, Everitt J, Farningham DA, Glennie MJ, Kelland LR, Robinson V, Stratford IJ, Tozer GM, Watson S, Wedge SR, Eccles SA (2010) Guidelines for the welfare and use of animals in cancer research Br J Cancer 102: 1555-1577.

Xu Q, Zhu S, Wang W, Zhang X, Old W, Ahn N, Liu X (2009) Regulation of kinetochore recruitment of two essential mitotic spindle checkpoint proteins by Mps1 phosphorylation. Mol Biol Cell 20(1): 10-20.
Yuan B, Xu Y, Woo JH, Wang Y, Bae YK, Yoon DS, Wersto RP, Tully E, Wilsbach K, Gabrielson E (2006) Increased expression of mitotic checkpoint genes in breast cancer cells with chromosomal instability. Clin Cancer Res 12(2): 405-410.

Zasadil LM, Andersen KA, Yeum D, Rocque GB, Wilke LG, Tevaarwerk AJ, Raines RT, Burkard ME, Weaver BA (2014) Cytotoxicity of paclitaxel in breast cancer is due to chromosome missegregation on multipolar spindles. Sci Transl Med 6(229): 229ra43.

(c) (i) This work is licensed under the Creative Commons Attribution 4.0 International License. To view a copy of this license, visit http://creativecommons.org/licenses/by/4.0/

(C) The Author(s) named above 2017

Supplementary Information accompanies this paper on British Journal of Cancer website (http://www.nature.com/bjc) 